\title{
わが国の都市間公共交通モビリティに関する時系列分析*
}

\section{Time Series Analysis of Intercity Mobility by Public Transportation Service in Japan*}

荒谷太郎**・轟朝幸***

By Taro ARATANI** • Tomoyuki TODOROKI***

\section{1. はじめに}

長距離の都市間移動では、鉄道・飛行機などの公共交 通機関の役割は大きく、わが国でも鉄道・空港等のイン フラ整備が着実に進められてきた。国民それぞれの移動 が円滑になるように都市間交通は整備されてきているが、 新幹線や空港整備などの大型プロジェクトは各地域から の政治圧力が強く、計画理念が地域計画や全国レベルの 交通計画として動かなかったことも多いと指摘されてい る ${ }^{1)}$ 。また、わが国では効率性・採算性が都市間交通 整備の唯一の評価基淮であるかのような議論も少なくな いとの指摘もある ${ }^{2)} 。 こ の$ 結果、新幹線のルートから 外れた地域は、新幹線が整備された地域と比較して都市 間移動の利便性が劣っている。空港整備では、ほとんど の都道府県に整備されてきたが、航空分野の規制緩和や 事業不振により、地方路線から撤退が相次ぎ、地方都市 間での移動利便性が低下してしまったと考えられる。さ らに近年の財政状況の悪化から、より費用対効果が重視 される傾向にあり、効果が少ない公共事業はますます整 備が遅れることが予想される。このような実態から、わ が国を全国的に見た場合に、都市間公共交通モビリティ は果たして向上してきているのかは疑問である。

そこで、本研究では、筆者ら ${ }^{3)}$ が提案しているモビリ ティの評価手法を用いて、わが国の1971年から2006年ま での整備や技術革新による都市間交通の利便性の動向を 明らかにすることを目的とする。

\section{2. わが国の都市間交通の変遷}

（1）鉄道ネットワークの変遷

1970年に制定された全国新幹線鉄道整備法では、現在 営業中の各線（表 1 ）や整備新幹線の他に、北海道南回 り、羽越 - 奥羽 - 中央 - 北陸中京 $\cdot$ 山陰 - 中国横断 -四 国 - 四国横断 - 東九州 ・ 九州横断の各新幹線が基本計画 *キーワーズ : 都市間交通、モビリティ、交通サービス、包絡分析法(DEA) **学生員、修 (工) 、日本大学大学院理工学研究科社会交通工学専攻

(千葉県船橋市習志野台7-24-1、TEL\&FAX : 047-469-5219) ***正員、博 (工) 、日本大学理工学部社会交通工学科
として示されている ${ }^{4)}$ (表 2）。新幹線の開業は、都 市間移動にかかる時間を短縮し利用者にとって利便性の 向上をもたらす。例えば、東北新幹線の盛岡一八戸間の 開業効果により、東京一八戸間の所要時間が約40分短縮 され、同様に北陸新幹線の高崎〜長野間の開業効果によ り、東京一長野間の移動が1時間40分短縮されるなど、 新幹線が開業している都市間では、都市間移動の利便性 が向上してきている。

表 1 新幹線の開業年と主な出来事

\begin{tabular}{|c|c|}
\hline 西暦 & 鉄道 \\
\hline 1964 & 東海道新幹線開業(東京一新大阪) \\
\hline 1972 & 山陽新幹線開業(新大阪－岡山） \\
\hline 1975 & 山陽新幹線延伸 (岡山一博多) \\
\hline 1982 & 東北·上越新幹線開業 (大宮－盛岡、大宮－新潟) \\
\hline 1985 & $\begin{array}{l}\text { 東北新幹線速度向上 }(210 \mathrm{~km} / \mathrm{h} \text { から } 240 \mathrm{~km} / \mathrm{h}) \\
\text { 東北新幹線延伸 }(\text { 大宮－上野 })\end{array}$ \\
\hline 1991 & 東北新幹線延伸 (上野一東京) \\
\hline 1992 & $\begin{array}{l}\text { 東海道新幹線速度向上 }(220 \mathrm{~km} / \mathrm{h} \text { から } 270 \mathrm{~km} / \mathrm{h}) \\
\text { 山形新幹線開業(福島一山形) }\end{array}$ \\
\hline 1997 & \begin{tabular}{|l} 
秋田新幹線開業(盛岡－秋田） \\
長野新幹線開業(高崎－長野) \\
\end{tabular} \\
\hline 2002 & 東北新幹線延伸(盛岡－八戸) \\
\hline 2003 & 品川駅開業 \\
\hline 2004 & 九州新幹線開業 (鹿児島中央－新八代) \\
\hline
\end{tabular}

表 2 全国新幹線鉄道整備法の定める基本計画

\begin{tabular}{|c|c|c|c|}
\hline 路線名 & 起点 & 終点 & 主要な経由地 \\
\hline 東北新幹線* & 東京都 & 青森市 & $\begin{array}{c}\text { 宇都宮市附近、 } \\
\text { 仙台市附近、 } \\
\text { 盛岡市 }\end{array}$ \\
\hline 上越新幹線* & 東京都 & 新潟市 & \\
\hline 北海道新幹線 & 青森市 & 旭川市 & $\begin{array}{c}\text { 函館市附近、 } \\
\text { 札幌市 }\end{array}$ \\
\hline 北陸新幹線* & 東京都 & 大阪市 & $\begin{array}{l}\text { 長野市附近、 } \\
\text { 富山市附近 }\end{array}$ \\
\hline 九州新幹線* & 福岡市 & 鹿児島市 & \\
\hline 九州新幹線 & 福岡市 & 長崎市 & \\
\hline 北海道南回り新幹線 & $\begin{array}{c}\text { 北海道山越郡 } \\
\text { 長万部町 } \\
\end{array}$ & 札幌市 & 室蘭市附近 \\
\hline 羽越新幹線 & 富山市 & 青森市 & $\begin{array}{c}\text { 新潟市附近、 } \\
\text { 秋田市附近 }\end{array}$ \\
\hline 奥羽新幹線 & 福島市 & 秋田市 & 山形市附近 \\
\hline 中央新幹線 & 東京都 & 大阪市 & $\begin{array}{c}\text { 甲府市附近、 } \\
\text { 名古屋市附近、 } \\
\text { 奈良市附近 }\end{array}$ \\
\hline 北陸-中京新幹線 & 敦賀市 & 名古屋市 & \\
\hline 山陰新幹線 & 大阪市 & 下関市 & $\begin{array}{c}\text { 鳥取市附近、 } \\
\text { 松江市附近 }\end{array}$ \\
\hline 中国横断新幹線 & 岡山市 & 松江市 & \\
\hline 四国新幹線 & 大阪市 & 大分市 & $\begin{array}{l}\text { 徳島市附近、 } \\
\text { 高松市附近、 } \\
\text { 松山市附近 }\end{array}$ \\
\hline 四国横断新幹線 & 岡山市 & 高知市 & \\
\hline 東九州新幹線 & 福岡市 & 鹿児島市 & $\begin{array}{l}\text { 大分市附近、 } \\
\text { 宮崎市附近 }\end{array}$ \\
\hline 九州横断新幹線 & 大分市 & 熊本市 & \\
\hline
\end{tabular}


このようにもしこの計画が全て実現すれば、日本全国 に新幹線ネットワークが整備され、全国各地の都市間移 動の利便性は高いものになると考えられる。しかし、現 状では整備新幹線の完成ですらかなりの時間を要してお り、今後、幹線鉄道サービスの全国的格差が早期に縮小 される可能性は極めて小さいといわれている5)。

(2) 航空ネットワークの変遷

表 3 に航空の主な出来事について整理を行った。2007 年現在、日本には離島を含めて97の空港がある。それゆ え、日本の空港整備は既成したといわれている。しかし、 石見、大館能代、能登などのローカル空港は、高い需要 見通しに基づいて建設されてきたため、結果的に多くは 過大な需要見通しになり、空港建設や改修は無䭾な投資 であるとの指摘もある ${ }^{6)}$ 。

航空政策では、1986年にそれまでの45/47体制を見直 し、航空政策を転換した。その後、段階的に競争政策を とり、1996年に需給調整規制を廃止した。2000年には、 新しい航空法が施行され、規制緩和が行われた。その主 な内容は、国際線の複数社体制、国内競争促進、日本航 空の完全民営化の3 点であった。これをきっかけにわが 国の航空ネットワークは競争促進と自由化一と進んでい った。この中で特に国内の移動に関わるのは、国内競争 促進であり、これは主に参入・撤退の自由、増減・廃止 の自由、運賃の自由化のことである7)。

参入・撤退の自由では、1986年に国内路線参入の基準 として、3 社運行路線は、年間旅客数 100 万人以上の路 線、 2 社運行は年間 70 万人以上の路線が打ち出された。 その後、参入基淮は段階的に緩和され、1997年に完全廃 止された。1998年には新規参入企業としてスカイマーク エアラインズが東京一福岡間に、北海道国際航空が東京 一札幌間に、2002年にはスカイネットアジア航空が東京 一宮崎間、2006年にはスターフライヤーが東京一北九州 間にそれぞれ参入している。これにより、新規参入企業 は需要の見込める幹線都市間へ参入を行い、幹線都市間 には、多くの航空会社が就航することとなり、運行本数 や割引運顀の面から利用者に利便性の向上をもたらした。 増減・廃止の自由化は、航空会社が自由に増便や減便 を行うことができることである。羽田空港に関しては、 発着枠増加のタイミングに、新規会社への割当てや既存 会社の増便などに限定されている。しかし地方空港では、 航空会社の事業不振から減便や廃止の要望が徐々に出て くるようになり、地方都市間を結ぶ不採算路線の減便や 廃止が進んできている。そのような都市間では、これま で直行便で移動できていたものが、乗り継ぎが必要とな り、運賃や所要時間が余計にかかる結果となり、利用者 に利便性の低下をもたらしている。
運顀の自由化は、1990年に同一距離・同一運賃帯への 移行と遠距離逢減の徹底を目指して標準原価が導入され、 それまで起きていた南北格差 (北海道や東北を結ぶ路線 の賃率が相対的に割高となっていたこと）の是正が図ら れた。1995年には50\%以内の営業割引運賃等が認可制か ら届出制になり、単身赴任割引や家族割引など新しい種 類の割引運賃が生まれた。1996年には標準原価から $25 \%$ 以内の幅で普通運賃設定が自由化され、2000年の航空法 改正で運賃はすべて届出制になった。この結果、幹線や 新規参入路線などでは割引率が高く設定され、それ以外 の地方路線などとの運賃格差が生じることとなった。

1986年からの規制緩和は、同一路線における 2 社運航、 3 社運航を推進することで、多様な割引運賃が登場し、 航空需要の喚起、消費者利便性の向上につながるという 一定の効果をもたらした。一方で航空会社の経営的な観 点から、地方・離島路線の減便・廃止という問題や割引 運賃の格差という問題を同時に抱えることとなった ${ }^{7)}$ 。 表 3 空港の開港年と主な出来事

\begin{tabular}{|c|l|}
\hline 年 & \multicolumn{1}{|c|}{ 航空の主な出来事 } \\
\hline 1965 & 松本空港開港 \\
\hline 1986 & 航空政策の転換 \\
\hline 1991 & 庄内空港開港 \\
\hline 1993 & $\begin{array}{l}\text { 石見空港開港 } \\
\text { 福島空港開港 }\end{array}$ \\
\hline 1994 & 関西国際空港開港 \\
\hline 1996 & 需給調整規制廃止 \\
\hline 1997 & 羽田C滑走路供用開始 \\
\hline 1998 & $\begin{array}{l}\text { 大館能代空港開港 } \\
\text { 佐賀空港開港 } \\
\text { スカイマークエアライン参入 }\end{array}$ \\
\hline 2000 & $\begin{array}{l}\text { 羽田B滑走路供用開始 } \\
\text { 航空運賃が届出制へ }\end{array}$ \\
\hline 2002 & $\begin{array}{l}\text { スカイットアジア航空参入 } \\
\text { 北海道国際航空入 参入 }\end{array}$ \\
\hline 2005 & 中部国際空港開港 \\
\hline 2006 & $\begin{array}{l}\text { 神戸空港開港 } \\
\text { スターフライター参入 }\end{array}$ \\
\hline
\end{tabular}

\section{3. 既存研究の整理}

都市間交通の既往研究は、奥村ら ${ }^{2)}$ や金子ら $^{8)}$ によ って整理されている。その中では、データ整理・交通行 動分析・評価手法などにおいて多様な課題があると指摘 している。そこで本研究では、まず交通分野における地 域格差についてレビューを行い、次に都市間交通の評価 に関連する既往研究についてレビューを行う。

交通分野における地域格差を扱った研究としては、移 動する際の価格差に注目したAndersonら ${ }^{9)}$ やKnapp ら ${ }^{10)}$ の研究がある。これらはいずれも費用（運賃）のみに着 目している。移動の容易さを評価する際には価格だけで は不十分であり、運行頻度や所要時間といった尺度も含 めた評価が必要である。

都市間交通の整備評価に関しては、鉄道・航空それぞ れに評価マニュアル11) 12)がある。その評価の中で、運行 
頻度や所要時間を含めた評価はされている。しかし、こ れらをモード別に評価することは、航空、鉄道をそれぞ れ整備する 2 重投資にもなりか祄なく、都市間公共交通 を整備するという視点からは、複数の交通モードを同時 に考える必要がある。

複数の交通モードによる移動利便性を評価している研 究としては、枦元ら ${ }^{13)}$ の研究がある。ある都市間の交 通ネットワークが改善されたときに発生する便益を地域 別に示す過程において、非集計選択モデルの効用を用い ることにより鉄道と航空の 2 つのモードを考慮している。 山口ら ${ }^{14)}$ は交通一般化費用を求める際に交通機関別の シェアを取り入れ、アクセシビリティ指標を算出してい る。天野ら ${ }^{15)}$ や川川ら ${ }^{16)}$ は、都市間交通における運行 頻度を考慮した新たな所要時間指標として、各時刻にお ける目的地までの所要時間を足し合わせた積み上げ所要 時間を定義している。菊池ら ${ }^{17)}$ は、この積み上げ所要 時間を用いた複数モードの期待一般化費用（EVGC）の算 出を行い、都市間交通の利便性が国土構造に与える影響 を経年的に明らかにしている。しかし、一般化費用を用 いる場合は時間価值を外生的に与えることが必要になる。 都市間交通の場合では、地域間で時間価值が異なること から、その扱いが複雑となる。このような問題から、時 間価值に頼らない都市間移動の利便性を評価する方法が 必要であると考える。また、アクセシビリティの総合指 標としてはログサム変数を採用している研究 ${ }^{18)}$ 19) もあ る。しかしログサム変数を用いた場合、都市間ごとにパ ラメータ推定する必要があり、対象ごとに多数のサンプ ルデータが必要となる。

そこで、本研究では、筆者ら ${ }^{3)}$ が提案している都市 間移動の地域格差を計測する都市間モビリティ指標を用 いて都市間交通の利便性の動向を明らかにする。この都 市間モビリティ指標は、DEA手法 ${ }^{20)} 21$ ）（包絡分析法）を 用いてD効率值を算出することによって定量評価するも のである。DEA手法は、企業や自治体の相対効率性を評 価する分析手法として開発されたノンパラメトリック手 法である。DEA手法では、統計的な検定はできないこと や、データにエラーがあった場合に結果がそのエラーに 影響を受ける可能性があること、また欠損值を含むデー 夕は扱えないという久点がある。一方で、アクセシビリ ティ指標の算出に用いられるようなログサム変数などの 抽象的統計モデルを決め、残差の分析に基づいてパラメ 一タ推定するという間接的な方法も、DEA手法では回避 することができる。つまり、パラメータ推定には多数の サンプルを必要とするが、DEA手法ではサンプルサイズ を問題としないといった利点がある。加えてDEA手法で は、複数の投入・産出項目を扱える。つまり、航空経路 のデータ・鉄道経路のデータというように複数交通モー
ドの経路を扱えることや、輸送実績や人口など評価項目 によって変数を加えることが可能であるといら利点があ る。その上、対象とする事業体 (Decision Making Unit 以下、DMU）間の効率性の違いを比率尺度によって定量 的に評価でき、また条件不利DMUへの改善案を具体的に 提言できるといった特徴がある。

\section{4. 都市間モビリティ指標}

（1）都市間モビリティ指標の概要

筆者らは、移動の容易さを表すモビリティ指標として 「個人モビリティ指標」「需要考慮モビリティ」「人口

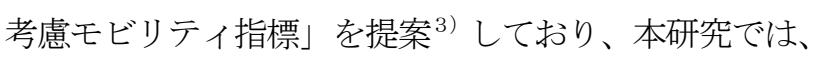
その評価手法を用いる（表 4）。

表 4 都市間モビリティ指標の評価内容

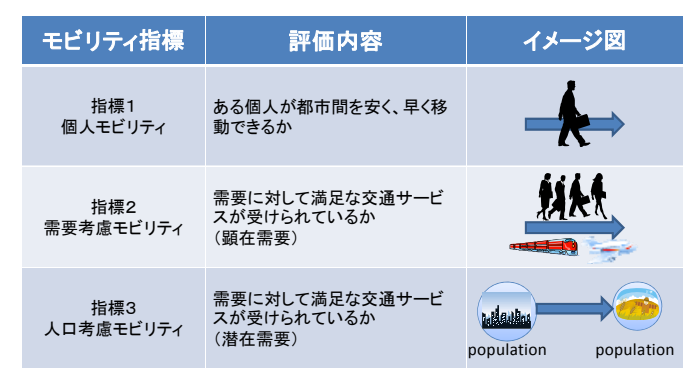

個人モビリティ指標は、個人が移動する際の目的地一 の移動の容易さを示した指標である。つまり、ある個人 が、都市間をどれだけ早く、安く移動できるかを評価す るものである。

需要考慮モビリティ指標、人口考慮モビリティ指標は、 それぞれ需要、人口に対して適切な交通サービスが提供 されているかを評価する。これは、現実には需要規模や 人口規模によって運行本数などの供給サービスが決まっ ているのが一般的であり、利用者もそのことをある程度 受容していると考えられる。そのため、需要規模を考慮 した指標および人口規模を考慮した、都市間モビリティ を計測する指標も用いる。この2つの指標は、それぞれ 輸送人員や人口が少ない都市間でよい交通サービスが提 供されている場合、モビリティが高い（逆に輸送人員や 人口が多いにも関わらず、悪い交通サービスの場合はモ ビリティが低い）と考える。つまり、需要規模や人口規 模を考慮することにより、都市間移動の顕在需要や潜在 需要に見合った公共交通サービスが提供されているかを 評価する指標である。

これらのモビリティ指標は、DEA手法 ${ }^{20)} 21$ *1を用いて D効率值を算出することによって定量評価するものであ る。図 1 はDEA手法を用いて都市間のモビリティを評価 する際のイメージ図を示している。DEA手法は、より少 ない投入量で多くの産出量が得られれば評価が高くなり、 
最も評価が高いものをD効率值 1 として評価する。つま り、移動の利便性が高い都市間ほどD効率值は 1 に近い 值となり、その反対に、移動の利便性が低い 都市間は、 D効率值 1 から離れた值となる。本研究では、DEAの分 析対象としての事業体 (DMU) を各都市間の交通サービ スと定義する。このサービスは都市間を個人が移動する 際に享受可能なものであり、つまり移動者にとってのモ ビリティを表すものである。

また本研究では、より良い交通サービスで長い距離が 移動できれば移動しや寸い都市間と定義する。例えば、 ある $2 つ の$ 都市間を比較した場合、同距離を移動するな ら、より早く移動できたほうが移動しやすい都市間であ るといえる。この場合、産出量は同距離のために同じで あり、投入量が少ない所要時間の短い都市間の方が $\mathrm{D}$ 効 率值は高くなる。本研究では、このD効率值を用いて都 市間公共交通モビリティの動向を考察することとする。

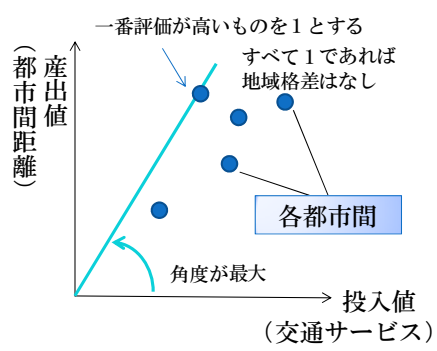

図1 DEA手法を用いた評価イメージ図

（2）DEA手法の概要

DEA手法は、開発された経緯から企業や自治体を評価 対象にした研究は多数見受けられるが、評価対象はこれ らに限らない。例えば、Chiouら ${ }^{22)}$ は、台湾の国内航空 路線を対象に、交通サービス評価を行っている。また、 $\mathrm{Graham}^{23)}$ の研究の中では、従業員数、車両定員、路線 長、客車走行キロを用いて都市鉄道の運行効率を評価し ている。しかし、DEA手法を複数の交通モードに適用し て、モビリティを評価している研究は筆者の知る限り存 在しない。

DEA手法には、主としてCCR (Charnes-Cooper-Rhodes) モデル ${ }^{24)}$ とBCC (Banker-Charnes-Cooper) モデル ${ }^{25)}$ がある。 CCRのモデル式を式(1)、式(2)に、BCCのモデル式を式 (3)、式(4)に示す。

$$
\begin{aligned}
& \operatorname{Max} \theta=\sum_{r=1}^{t} u_{r} y_{r 0} \\
& \text { Subject to: } \sum_{i=1}^{m} v_{r j} x_{i 0}=1 \\
& \sum_{r=1}^{t} u_{r} y_{r j}-\sum_{i=1}^{t} v_{i} x_{i j} \leq 0 \\
& u_{r}, v_{i} \geq \varepsilon \\
& i=1, \cdots, m \quad j=1, \cdots, n \quad r=1, \cdots, t
\end{aligned}
$$


数などの交通サービスは需要規模に応じて S 字曲線的に 変化することも知られており、規模の収穫は一定でない 部分もある。そのため、BCCモデルを用いた分析も併せ て行う。

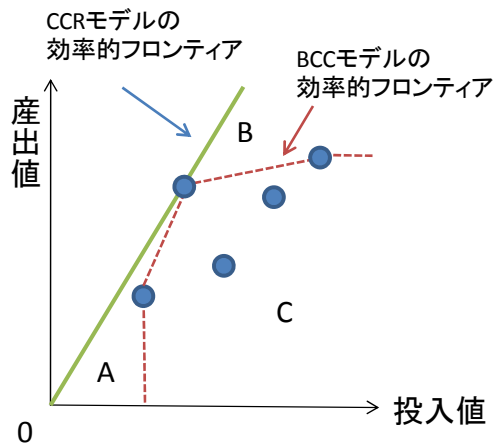

図 2 生産可能領域と効率的フロンティア

(3) 時系列分析の方法

DEA手法において、時系列的に効率性の変化を測定す る代表的な方法として、マルムキスト指数を用いる方法 とウィンドー分析法がある。

マルムキスト指数は、生産性変化を示す指標であるが、 生産性変化を技術効率性変化と技術変化(フロンティ ア・シフト)に分離して計測することを可能な指標であ る。またウィンドー分析は、時系列的にデータがある場 合に、各時点におけるDMUを独立した活動とみなして時 系列的に効率性の測定を行い、その变化の傾向をみるこ とができる手法である。

ウィンドー分析では、マルムキスト指数では分かるよ うなD効率值の上昇による理由が技術効率性变化と技術 変化(フロンティア・シフト)なのかはわからない。しか し本研究では、出力される結果が単年度で分析されたも のと同じD効率值で算出され、結果が直感的に理解しや すい ${ }^{27)}$ というウィンドー分析を用いて時系列分析を行 うこととする。なお本研究は、都市間ごとの評価をして いるが、鉄道の場合、交通サービスが改善された区間を 利用するすべての都市間において改善され効果が広範囲 に及ぶことに留意する必要がある。

ウィンドー分析は、隣接する 2 期を比較対象としたウ インドー分析や総当たり方式のウィンドー分析などがあ る。後者の総当たり方式のウィンドー分析のほうが、時 系列変化をより多く測定でき、実証結果として信頼度を 高めることができる28) ことより、本研究では、総当た り方式のウィンドー分析法を用いる。

総当たり方式のウィンドー分析法の手順は、以下のと おりである ${ }^{21)}$ 。説明を簡略化するために 3 期間の場合 を例として説明をする。
(1) まず、1つの期だけを対象にD効率性を計算する。 即ち 1 期、 2 期、 3 期の活動を対象として 3 通り。

(2) 次に、2つの期のすべての組み合わせについてD 効率性を計算する。即ち 1 期 -2 期、 1 期 -3 期、 2 期 -3 期の 3 通り。

(3) 最後に、3つの期を全部一緒にしてD効率性を計 算する。即ち 1 期 -2 期 -3 期の 1 通り。

表 5 にその結果を示す。この表の $\theta_{\mathrm{A} 1,13}$ は、1期-3 期の組合せで計算したときの $\mathrm{A}_{1}$ （Aの第 1 期）のD効 率值を意味する。この表の值を横に平均すれば、各活動 の各期の評価值（ $\theta_{\mathrm{A} 1}$ など）が得られ、さらにそれを縦 に平均すれば、各活動の全期間を通しての評価值（ $\theta_{\mathrm{A}}$ など）がわかる。ここでは3期間の場合を説明したが、 一般にn期間になったときは、期の組合せの総数は $2 n-1$ になる。

表 5 総当たり式ウィンドー分析の組合せ表

\begin{tabular}{|c|c|c|c|c|c|c|}
\hline 社·期 & \multicolumn{4}{|c|}{ 組合せ } & 平均 & $\begin{array}{l}\text { 各社 } \\
\text { 平均 }\end{array}$ \\
\hline $\mathrm{A} 1$ & $\theta_{\mathrm{A} 1.1}$ & $\theta_{\mathrm{A} 1,12}$ & $\theta_{\mathrm{A} 1,13}$ & $\theta_{\mathrm{A} 1.123}$ & $\theta_{\mathrm{A} 1}$ & \\
\hline A2 & $\theta_{\mathrm{A} 2,2}^{\mathrm{A}, 1}$ & $\theta_{\mathrm{A}, 2,22}^{\mathrm{A}, 12}$ & $\theta_{\mathrm{A}, 2,23}^{\mathrm{A}, 13}$ & $\theta_{\mathrm{A}, 1,123}$ & $\theta_{\mathrm{A} 2}^{\mathrm{A} 1}$ & \\
\hline A3 & $\theta_{A 3,3}^{A, 2}$ & $\theta_{A 3,13}^{A \alpha, 22}$ & $\theta_{A, 23,23}$ & $\theta_{A 3,123}^{A, 23}$ & $\theta_{\mathrm{A} 3}$ & $\theta_{A}$ \\
\hline B1 & $\theta_{\mathrm{B} 1,1}$ & $\theta_{\mathrm{B} 1,12}$ & $\theta_{\mathrm{B} 1,13}$ & $\theta_{\mathrm{B} 1,123}$ & $\theta_{\mathrm{B} 1}$ & \\
\hline B2 & $\theta_{\mathrm{B} 2,2}^{\mathrm{B}, 1}$ & $\theta_{\mathrm{B} 2,22}$ & $\theta_{\mathrm{B} 2,23}$ & $\theta_{\mathrm{B} 2,123}$ & $\theta_{\mathrm{B} 2}$ & \\
\hline B3 & $\theta_{\mathrm{B} 33}^{\mathrm{DL2}, \mathrm{Z}}$ & $\theta_{\mathrm{B} 3.13}^{\mathrm{D}, 2 \mathrm{t}}$ & 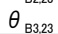 & $\theta_{\mathrm{B} 3,123}^{\mathrm{DD}, 12 \mathrm{O}}$ & $\theta_{\mathrm{B} 3}^{\mathrm{DC}}$ & $\theta_{B}$ \\
\hline $\mathrm{C} 1$ & $\theta_{c 1,1}$ & $\theta_{c 1,12}$ & $\theta_{c 1,13}$ & $\theta_{01,123}$ & $\theta_{\mathrm{c} 1}$ & \\
\hline $\mathrm{C} 2$ & $\theta_{c 2,2}$ & $\theta_{\mathrm{C} 2,22}$ & $\theta_{\mathrm{C} 2,23}$ & $\theta_{C 2,123}$ & $\theta_{\mathrm{C} 2}$ & \\
\hline C3 & $\theta_{c 3.3}$ & $\theta_{c 3.13}$ & $\theta_{\mathrm{C} 3.23}$ & $\theta_{c 3.123}$ & $\theta_{\mathrm{C} 3}$ & $\theta_{c}$ \\
\hline D1 & $\theta_{01,1}$ & $\theta_{D 1,12}$ & $\theta_{\mathrm{D} 1,13}$ & $\theta_{\mathrm{D} 1,123}$ & $\theta_{\mathrm{D} 1}$ & \\
\hline D2 & $\theta_{02,2}$ & $\theta_{\mathrm{D} 2,22}$ & $\theta_{\mathrm{D} 2.23}$ & $\theta_{\mathrm{D} 2,123}$ & $\theta_{\mathrm{D} 2}$ & \\
\hline D3 & $\theta_{\mathrm{D} 33}^{U_{2,4}}$ & $\theta_{\mathrm{D} 3.13}$ & $\theta_{\mathrm{D} 323}$ & $\theta_{03,123}$ & $\theta_{\mathrm{D} 3}$ & $\theta_{0}$ \\
\hline
\end{tabular}

（4）都市間モビリティの分析条件

本研究では、都市間の公共交通サービスとして、航空、 鉄道（一部高速バスを含む ${ }^{* 2}$ ) を対象とした。各都市間 の交通サービスは、移動する経路によって異なっている。 しかし、実際に利用されている経路に基づいた交通サー ビスデータを取得することは困難である。そこで本研究 では、都市間を移動する利用者がもつとも多く利用する であろう所要時間最小経路の交通サービスデータを用い て分析を行うこととした。その所要時間最小経路の交通 サービスデータは、国土交通省が開発したNITAS（総合 交通分析システム) Ver.1.7を用いて算出した。対象の 都市間は、都道府県庁を起終点とする $200 \mathrm{~km}$ 以上の781都 市間とし、DEA手法では欠損值が扱えないため、同一空 港が最寄りとなる都市間は除いた。各データは、1971年 度、1981年度、1991年度、2001年度、2006年度の結果を 用いた。このNITASより算出されるデータは、運賃 (正 規運賃）、所要時間（アクセス、イグレス時間を含む） その他時間*3 (待ち時間、乗り換え時間) である。この その他時間は、便数が多いほど小さくなるような便数サ 
ービスの代理変数と考えることができる。この他、鉄道、 航空の各輸送人員は、全国幹線旅客純流動調查の代表交 通機関別幹線旅客流動量 ${ }^{29}$ より（データは1990年度、 2000年度、2005年度を使用）、各都道府県の人口は総務 省の人口推計データ ${ }^{30)}$ を用いた。なお、物価上昇など に応じた時代間の貨幣価値の相違を考慮して、運賃は内 閣府のGDPデフレーターを用いて実質化している。時間 に対する価值観も時代によって変化するが、その大きさ は物価変動ほど大きくないと思われるため、ここでは考 慮していない。

また、3つのモビリティ指標は、それぞれ表 6 に示す 入出力項目を設定した。入力項目は、3つの指標ともに 利用者が都市間移動をする際に直接関係する鉄道・航空 の運顀、所要時間、その他時間とした。出力項目は、個 人モビリティでは、利用者が移動した結果としての都市 間距離（直線距離）のみとした。需要考慮モビリティで は、鉄道・航空といった公共交通で移動する都市間需要 に、どれだけ見合った交通サービスがその都市間に提供 されているのかという観点から評価するため、出力項目 に鉄道と航空のそれぞれの輸送人員の和を採用した。人 口考慮モビリティでは、両都市の人口を扱う際に重力モ デルを参考にして、両都市の人口の積を都市間人口変数 と定め出力項目として採用した。

DEA手法で算出される結果は、より少ない入力で多く の出力を得られれば効率的であると評価される。そのた め、入力項目には少なければ少ない方がよいもの、出力 項目には多ければ多いほどよいものを扱う必要がある。 これとは逆向きの変数がある場合、モデル入力において は数值を変換する必要がある ${ }^{21)}$ 。本研究では、輸送人 員や人口が少ない都市間でよい交通サービスが与えられ ている場合、モビリティが高い（逆に輸送人員や人口が 多いにも関わらず、悪い交通サービスの場合はモビリテ イが低い）と考える。そのため、出力項目の人口の変数 は、人口変数は逆数変換を施すことにした。また、出力 項目の輸送人員は、都市間によっては 0 あり、逆数変 換ができない。そのため、式(5)を用いて大小変換21) ${ }^{31}$ を行い、輸送人員変数 $D^{\prime A}$ としてモデル上で扱っている （非負にするため最小の整数值である1を加えている）。

$$
D^{A}=2 \mu-D^{A}+1
$$

ここで、 $D^{A}$ は輸送人員、 $\mu$ は最大值と最小值の平 均を示す。
表 6 DEA手法によるモビリティ計測の設定条件

\begin{tabular}{|c|c|c|}
\hline 指標 & 入力項目 & 出力項目 \\
\hline 個人モビリティ & $\begin{array}{c}\text { 鉄道運賃(円) } \\
\text { 鉄道所要時間(分) } \\
\text { 鉄道その)他時間(分) } \\
\text { 航空運賃(円) } \\
\text { 航空所要時間(分) } \\
\text { 航空その他時間(分) }\end{array}$ & 都市間距離(km) \\
\hline $\begin{array}{l}\text { 需要考慮 } \\
\text { モビリティ }\end{array}$ & $\begin{array}{c}\text { 鉄道運賃(円) } \\
\text { 鉄道所要時間(分) } \\
\text { 鉄道その他時間(分) } \\
\text { 航空運賃(同) } \\
\text { 航空所要時間(分) } \\
\text { 航空その他時間(分) }\end{array}$ & $\begin{array}{l}\text { 輸送人員(千人) } \\
\text { 都市間距離 }(\mathrm{km})\end{array}$ \\
\hline $\begin{array}{l}\text { 人口考慮 } \\
\text { モビリティ }\end{array}$ & $\begin{array}{c}\text { 鉄道運賃(円) } \\
\text { 鉄道所要時間(分) } \\
\text { 鉄道その他時間(分) } \\
\text { 航空運賃(円) } \\
\text { 航空所要時間(分) } \\
\text { 航空その他時間(分) }\end{array}$ & $\begin{array}{c}\text { 都市間人口変数(千人²) } \\
\text { 都市間距離 }(\mathrm{km})\end{array}$ \\
\hline
\end{tabular}

\section{5. 都市間モビリティの時系列分析}

図 3、図4は、CCRモデル及びBCCモデルを用いて算出 した781都市間のD効率值の平均值を示している。この 平均值は、わが国全体でのモビリティ水準の変化を表し ており、D効率值の変化が上昇していればわが国全体で のモビリティの水準は向上しており、減少していれば悪 化したことを示している。また、D効率值の変化は、例 えばD効率值0.2から0.4に改善された場合は、1からの 悱離度合いが、80\%から60\%となったことを意味してい るため、都市間モビリティが $20 \%$ 改善したことを示して いる。

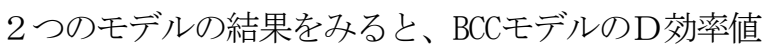
はCCRモデルより全般的に高い值を示した。これは、モ ビリティの向上は交通サービスの向上に対して逓増傾向 にある（規模の経済性が働いている）ことを表している。 しかし、需要考慮モビリティの1991年と2006年では規模 の経済性が働いていない結果であった。これは、両年に おいてCCRモデルのフロンティアに近いフロンティアが BCCモデルにおいても形成されたのではないかと推察で きる。

また両モデル共通の傾向として、個人モビリティ、人 口考慮モビリティについては1971年から1991年まで上昇 傾向にある。これは、GDPデフレーターより物価指数が 0.473から1.092（2006年=1とした場合）と2倍以上に上 昇しているため、航空・鉄道の運賃が実質安くなったこ とが影響しているといえる。1991年以降はD効率值が 徐々に減少傾向となった。1991年から2001年の間には、 山形、秋田、長野新幹線が開通し、加えて1992年には東 海道新幹線が最高速度を $220 \mathrm{~km} / \mathrm{h} か ら 270 \mathrm{~km} / \mathrm{h}$ 、1997年 には東北新幹線の最高速度が $240 \mathrm{~km} / \mathrm{h} か ら 275 \mathrm{~km} / \mathrm{h}$ に速度 向上している。航空では1994年に関西国際空港が開港し ている。そのため、これらによる所要時間の短縮やその 他時間の短縮の恩恵が受けられる都市間では、これらの 
要因によって都市間モビリティが向上した。しかし、こ れらの整備効果でのD効率值の改善は一部の都市間に限 られ、むしろ1995年にJR北海道、四国、九州が、運賃を 7. $0 \%$ ～ $8.0 \%$ の值上げを行っており、その影響がわが国 全体の都市間モビリティを悪化させたため、1991年から 2001年は減少傾向になったと考えられる。

需要考慮モビリティでは、1991年から2001年にはD効 率值が上がっているが、2006年度には再び低下している。 これは、国内の輸送人員の減少が影響したためである。

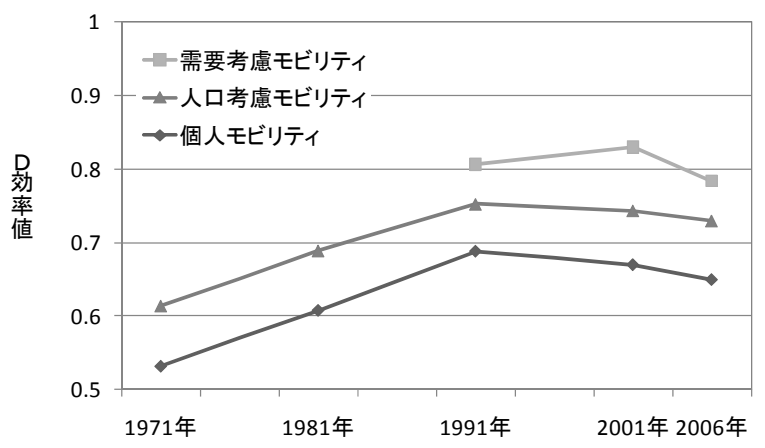

図 3 都市間モビリティの時系列変化(CCRモデル)

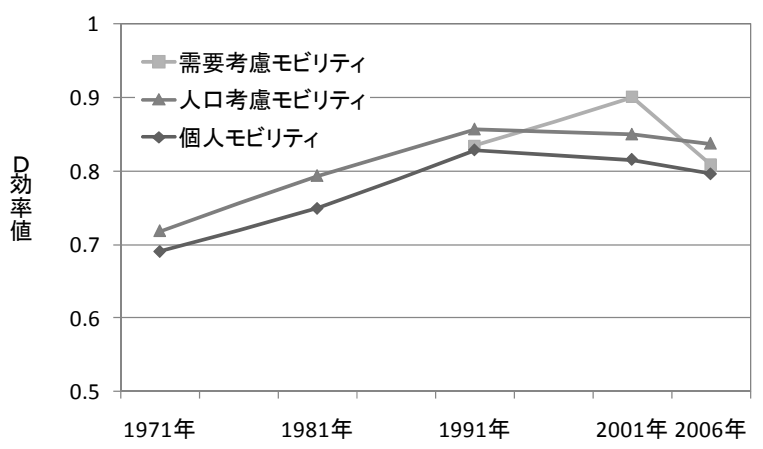

図4 都市間モビリティの時系列変化(BCCモデル)

次に、CCRモデルの結果を用いてD効率值を算出し、 その変化に特徵のある都市間について図 $5 \sim 7 に$ 示した。

図 5 は千葉一長野、新潟一兵庫の個人モビリティを 示している。千葉一長野は1991年度から2001年度にかけ て、D効率值が低下している。これは、1997年に長野新 幹線が開業する前は、高速バスが350分で所要時間最小 の経路であったが、新幹線開業により鉄道が205分と所 要時間最小経路となり、それによって移動費用が大幅に 上昇したことで、D効率值が低下したものと考えられる。 新潟一兵庫においては、1972年に山陽新幹線が新大阪一 岡山が開業したことにより、所要時間最小経路が今まで の富山を経由し490分かかっていたものが、東京を経由 し新幹線を利用寸る414分かかる経路に変化したため運 賃が上昇し、D效率值が低下したものと考えられる。こ れらの結果は、所要時間最小経路にて所要時間と運貨を
算出したためとも考えられる。そのため実態を反映した 経路のデータを利用した場合、より精緻な結果が算出さ れるといえる。

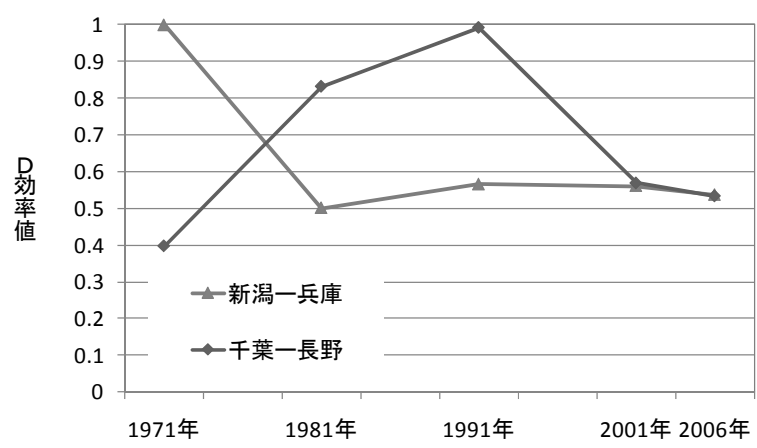

困 5 個人モビリティの時系列分析結果

図6は、北海道一岐阜、三重一鹿児島の需要考慮モビ リティの時系列変化を示したものである。北海道一岐皁 は、D効率值が2001年度から2006年度にかけて上昇して いる。これは、輸送人員は 81 千人から 71 千人と減少して いるが、航空その他時間が改善されており、中部国際空 港開港における航空の運航本数の増加によるその他時間

(待ち時間) の減少が $\mathrm{D}$ 効率值上昇の要因として考えら れる。

三重一鹿児島は、2001年度までは大阪国際空港を利 用する経路だったが、2006年度では中部国際空港を経由 するルートの方が30分早くなった。これにより利便性が 向上し、輸送人員は 28 千人から 31 千人と若干増えたにも 変わらず、航空運賃が上昇したためD効率值が低下した ものと考えられる。

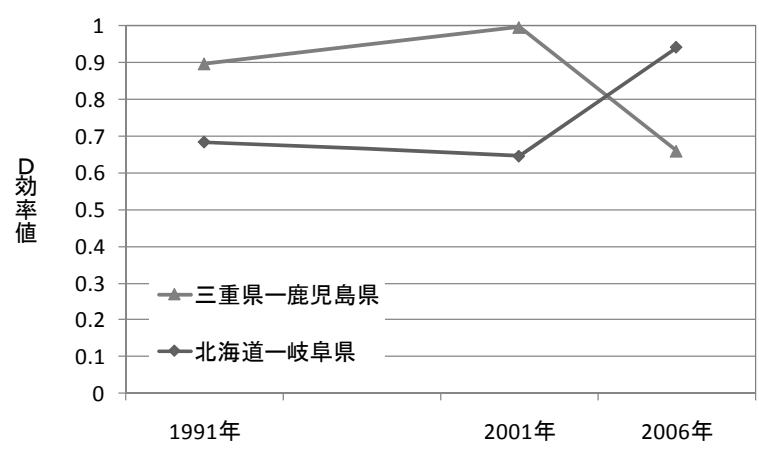

図6 需要考慮モビリティの時系列分析結果

図 7 は、高知一佐賀の人口考慮モビリティの時系列 変化を示したものである。高知県は1991年より、佐賀県 は2001年より人口が減少傾向にあり、人口が減少したこ とにより D効率值が高くなった都市間であるといえる。 愛媛一鹿児島は、1978年に直行便が就航したことにより、 航空の所要時間が46分短くなった。それにより1981年で 
の効率值が上昇している。それ以降、直行便は保たれ、 徳島、鹿児島両県の人口は減少したため、D効率值は上 昇している。しかし、他の都市間の利便性が向上してい るため、2001年以降はD効率值が低下したものと考えら れる。

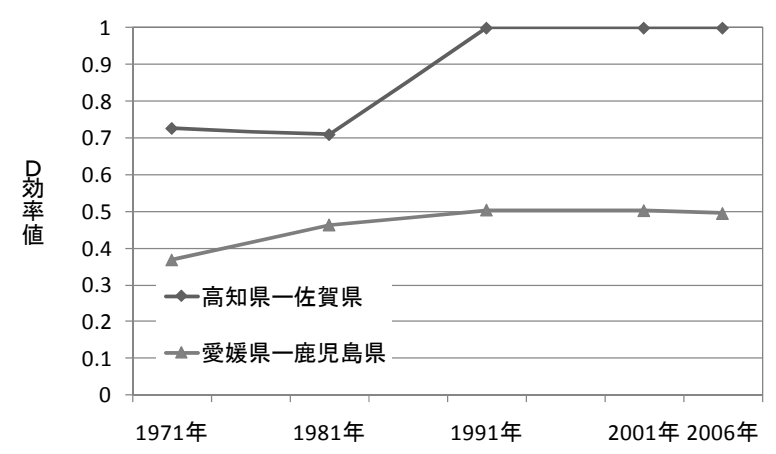

図 7 人口考慮モビリティの時系列分析結果

\section{6. おわりに}

本研究では、DEA手法を援用したモビリティ指標を用 いて、1971年から2006年までの交通施設整備や技術革新 などによる都市間交通の利便性の動向を明らかにした。 新幹線開業や速度向上によって、1991年まではモビリテ イが向上していたものの、それ以降は鉄道や航空の運顀 が実質的に上昇したことにより再び低下していたことが わかった。しかし、需要考慮モビリティでは、分析結果 より、需要の増減と交通サービスの変化が都市間モビリ ティの変化に与えている影響が明らかになった。

特に迂回経路を利用しなければならない都市間では、 運賃や所要時間の増加につながり、モビリティが低下し やすい要因のひとつであるといえる。つまりこのような 都市間が存在する場合は、乗り継ぎの割引運賃などを設 定することが必要であるといえる。

今後の課題としては、まず、データの精緻化が挙げら れる。とくに航空運賃は規制緩和後に多様化しており、 実勢運賃を表現できるデータを用いることが規制緩和の 影響分析には必要となる。また、都市間の移動経路も多 様であり、最小時間経路のみが利用されているとは限ら ないことから、この扱いについてさらなる検討が必要で ある。そのため、新たなデータの取得と精緻化を行うこ とにより、より現実的な結果が算出されるといえる。

2 点目は、モビリティの低下を防ぐための割引運賃や 乗り継ぎ運賃を用いたモビリティ変化を把握し、より効 果的な施策を探ることも今後の課題である。

\section{謝辞}

本研究は、国土交通省が開発した NITAS（総合交通分 析システム) Ver1.7 を使用させていただきました。こ
こに付記し謝意を表します。また本研究は、文部科学省 科学研究費補助金基盤研究（C）21560560「都市間交通 におけるモビリティの地域格差分析」の助成を受けてい ます。ここに感謝の意を表します。

補注

*1 具体的な計算例は、参考文献 21 を参照のこと。

*2 NITAS における鉄道の所要時間最小経路の算出結 果は、鉄道よりも高速バスの方が所要時間最小となる場 合には、高速バスを利用する経路として算出される。

*3 その他時間は、主に待ち時間と乗り換え時間を示 しており、運行頻度の代理指標として用いている。

\section{参考文献}

1）高田邦道 : 豊かな地方にするためには、国土と政策 No. 28、pp. 16-19、2009.

2）奥村誠、中川大、山口勝弘、土谷和之、奥村泰宏、 日野智、塚井誠人 : 都市間交通の分析と評価の課題、 土木計画学研究・講演集Vol, 25、CD-ROM、2002.

3）荒谷太郎、轟朝幸、金子雄一郎 : 公共交通サービス による都市間移動の地域格差分析、土木計画学研 究・論文集 Vol. 26、no. 4、pp. 807-816、2009.

4）高速鉄道研究会著 : 新幹線一高速鉄道の技術のす心 て、山海堂、2003.

5 ）波床正敏、中川大 : 幹線鉄道におけるハブシステム 構築の効果と意義に関する研究-スイスの鉄道政策 Rai12000の効果分析を踏まえて一、都市計画論文集 No. 41-3、pp. 839-844、2006.

6 ）（株）ANA総合研究所編著 : 航空産業入門、東洋経 済新報社、2008.

7 ）山内弘隆：日本の航空事情について、航政研シリー ズ、No. 483、pp. 111-129、2007.

$8 ）$ 金子雄一郎、加藤浩徳 : 我が国の都市間交通研究の 系譜、土木計画学研究・講演集Vol31、CD-ROM、 2005.

9) Anderson W. P., GONG G., LAKSHMANAN T. R. : Geographical Variation in Cost of Air Travel. Analysis of the Domestic Airline Fares Consumer Report, Transport Research Record, No. 1788 pp. 13-18, 2002.

10) Knapp S. F., Lago A. M. : Results of a Parametric Cost Analysis of Differences between Urban and Rural Transportation Services for Transportation -disadvantaged Persons, Transport Research Record, No. 934 pp. 1-8, 1983. 
11）国土交通省航空局 : 空港整備事業の費用対効果分析 マニュアルVer. 3、2004.

12）運輸省鉄道局監修 : 鉄道プロジェクトの費用対効果 分析マニュアル99、財団法人運輸政策研究機構、 1999.

13）枦元淳平、塚井誠人、奥村誠：複数経路を考慮し た鉄道・航空ネットワークの評価、土木計画学研究 論文集No. 20、 pp. 255-260、2003.

14）山口勝弘、幕亮二 : 都道府県間アクセシビリティ改 善の経済効果、交通学研究2003年研究年報、 Page. 9-19、2003.

15）天野光三、中川大ら : 都市間交通における所要時間 の概念に関する基礎的研究、土木計画学研究・論文 集No. 9、pp. 69-76、1991.

16）中川大、波床正敏ら：国際交通分析における利便性 指標としての積み上げ所要時間に関する研究 : 土木 学会論文集No590/IV-39、pp. 43-50、1998.

17）菊池隆史、中川大、大庭哲治 : フリークエンシーを 考慮した都市間交通利便性と地域発展及び国土構造 との関係に関する研究、都市計画論文集No43-3、pp. 247-252、2008.

18）宮本和明、北詰恵一、磯野文暁 : 都市交通基盤およ び関連施設整備がもたらす便益の相乗効果を考慮し た起源別計測、日本不動産学会誌Vol. 15 N0.4 pp. 59-67、2002.

19）加藤浩徳、金子雄一郎、井上真志 : 交通プロジェク 卜の利用者便益評価における0D間代表一般化費用に 関する諸問題ーロジットモデルを用いる場合のケー ススタディー、運輸政策研究 Vol. 6 No. 1、pp. 23-38、 2003.

20) Charnes A. ら、刀根薰ら監訳 : 経営効率評価ハンド ブックー包絡分析法の理論と応用一、朝倉書店、 2000.

21）刀根董 : 経営効率性の測定と改善、日科技連、1993.

22) Chiou, Y. -C., Chen, Y. - H. : Route-based performance evaluation of Taiwanese domestic airlines using data envelopment analysis, Transportation Research Part E 42 (2), pp. 116127, 2006.

23) Graham Daniel J. : Productivity and Efficiency in Urban Railways: Parametric and nonparametric estimates, Transport Research E Policy, Vol. 44 No. 1 pp. 84-99, 1992.

24) Charnes, A., Cooper, W. W. and Rhodes, E. L. : Measuring the Efficiency of Decision Making Unites, European Journal of Operational Research Vol.2, pp. 429-444, 1978.
25) Banker, R. D., Charnes, A., Cooper, W. W. : Some Models for Estimating Technical and Scale Inefficiencies in Data Envelopment Analysis, Management Science, Vol. 30, pp. 401-425, 1984.

26）末吉俊幸 : DEA-経営効率分析法、、朝倉書店、2001.

27）杉山学: データ包絡分析法によるJRと大手私鉄の事 業活動効率比較、群馬大学社会情報学部研究論集16、 pp. 61-82、2009.

28）末吉俊幸 : DEA/WINDOW分析法による電気通信事業体 の経営効率と規模の経済性の比較、検討、オペレー ションズ・リサーチ37、pp. 210-219、1992.

29）国土交通省：全国幹線旅客純流動調查 第 1 回～第 4 回、

http://www. mlit. go. jp/seisakutokatsu/ jyunryuud ou/index. html

30）総務省 : 人口推計データ、 http://www. stat. go. jp/data/jinsui/index. htm

31) 原潔、黄少雄 : 包絡分析法(DEA) による船舶運航の 効率性評価、日本航海学会論文集No. 96、pp. 149155、1997. 


\section{わが国の都市間公共交通モビリティに関する時系列分析*}

荒谷太郎**・轟朝幸***

わが国の都市間交通は、新幹線を中心とする鉄道ネットワークに加え、ほとんどの都道府県に空港が整備さ れ、航空ネットワークも充実してきている。しかし、地域別にみると新幹線のルートから外れた地域や、航空 の不採算路線の廃止による地方路線からの撤退により、移動の利便性が低下した都市間もある。

本研究では、DEA手法を援用したモビリティ指標を用いて、1971年から2006年までの交通施設整備や技術革 新による都市間交通の利便性の動向を明らかにした。その結果、新幹線開業や速度向上によって、1991年まで はモビリティが向上していたものの、それ以降は鉄道や航空の運賃が実質的に上昇したことにより再び低下し ていたことがわかった。

\section{Time Series Analysis of Intercity Mobility by Public Transportation Service in Japan*}

By Taro ARATANI**•Tomoyuki TODOROKI***

In recent years, intercity mobility in Japan has steadily improved as a result of deregulation in the transport sector, improved transportation facilities, technical innovations, and other factors. However, focusing in local intercity mobility, there are becoming low intercity mobility due to the city located off Shinkansen route and withdrawal from less profitable business.

In this study, progressive shifts of intercity mobility in Japan from 1971 to 2006 by the policies for improvement of highspeed railways, deregulation of air services and so on were clarified by using Data Envelopment Analysis. As a result, it is shown intercity mobility becomes higher by improvement of high-speed railways until 1991. However, intercity mobility becomes decrease by rising air and train fare after 1991. 